\title{
Paradoxical glycaemic response to surgical treatment of ovarian hyperthecosis in a patient with type 2 diabetes
}

\author{
KATE E SHIPMAN ${ }^{1}$, CHANDNI SINHA², SANJAY SARAF³ , JOHN J MILLES ${ }^{4}$, MICHAEL MOLONEY5, \\ SUDARSHAN RAMACHANDRAN ${ }^{1}$
}

\begin{abstract}
Introduction
Ovarian stromal hyperthecosis in post-menopausal women is a rare disorder characterised by gradual virilisation and features of the metabolic syndrome similar to PCOS. ${ }^{1}$ Improvement of diabetic control in hyperthecosis has been reported following oophorectomy, perhaps secondary to normalisation of the hyperandrogenaemia. ${ }^{2}$ This is a report of worsening diabetes following oophorectomy. The case and possible explanations for the response are described.
\end{abstract}

\section{Case report}

A 56 year-old post-menopausal woman with type 2 diabetes was referred to the diabetes clinic in January 2002, the diabetes having been diagnosed in 2001 following an ischaemic stroke. Glycaemic control was poor with dyslipidaemia and elevated liver enzymes (Table 1). Hepatic steatosis was suggested on ultrasound in keeping with the lipid and liver function tests. Oral hypoglycaemic agents were converted to a basal bolus insulin regime on referral in 2002, resulting in a reduction of $\mathrm{HbA}_{1 \mathrm{c}}$ from $9.4 \%$ to $6.8 \%$.

In 2005 the patient complained of gradual onset male pattern balding and excessive hair over the face, forearms, shoulders and legs that had been developing over two years. Results (reference range) showed that total and free testosterone concentrations were elevated at $6.7 \mathrm{nmol} / \mathrm{L}(<1.7)$ and 24.7 $\mathrm{pmol} / \mathrm{L}(4.5-19.4)$ respectively, with SHBG low at $4.7 \mathrm{nmol} / \mathrm{L}$

\footnotetext{
Department of Clinical Biochemistry, Good Hope Hospital, Heart of England NHS Foundation Trust, UK

Medical School, University of Birmingham, UK

Department of Acute Medicine, Walsall Manor Hospital, UK

4 Department of Diabetes \& Endocrinology, Good Hope Hospital, Heart of England NHS Foundation Trust, UK

Department of Obstetrics \& Gynaecology, Good Hope Hospital, Heart of England NHS Foundation Trust, UK
}

Address for correspondence: Dr Kate Shipman

Department of Clinical Biochemistry, Good Hope Hospital, Heart of

England Foundation Trust, Rectory Road, Sutton Coldfield, West Midlands,

B75 7RR, UK

Tel: $+44(0) 1214247246$

E-mail: kate.shipman@doctors.net.uk

Br J Diabetes Vasc Dis 2015;15:37-39

http://dx.doi.org/10.15277/bjdvd.2014.039

\author{
Abbreviations and acronyms \\ CT computed tomography \\ DHEAS dehydroepiandrosterone sulphate \\ FSH follicle stimulating hormone \\ GGT Y-glutamyl transferase \\ $\mathrm{GnRH} \quad$ gonadotropin releasing hormone \\ $\mathrm{HbA}_{1 \mathrm{c}}$ haemoglobin $\mathrm{A}_{1 \mathrm{c}}$ \\ HPLC high performance liquid chromatography \\ HDL-C high density lipoprotein cholesterol \\ LDL-C low density lipoprotein cholesterol \\ $\mathrm{LH} \quad$ luteinising hormone \\ PCOS polycystic ovarian syndrome \\ PPAR peroxisome proliferator activated receptor \\ SHBG sex hormone binding globulin
}

(31.0-93.0). Androstenedione was marginally elevated at 13.1 $\mathrm{nmol} / \mathrm{L}(1.7-12.9)$ and FSH and oestradiol were low at $13.7 \mathrm{IU} / \mathrm{L}$ (post-meonopausal: 26.7-133.4) and $<73.4 \mathrm{pmol} / \mathrm{L}$ (postmenopausal: 37-1028) respectively. The rest of the results were within the normal reference ranges; LH $12.3 \mathrm{IU} / \mathrm{L}$ (postmeonopausal: 5.2-62.0), DHEAS $0.9 \mu \mathrm{mol} / \mathrm{L}(0.0-5.4)$, random cortisol $351 \mathrm{nmol} / \mathrm{L}$ and prolactin $544 \mathrm{mIU} / \mathrm{L}$ (98-784). Thyroid function tests and renal function were unremarkable.

Abdominal and pelvic CT scan did not reveal any pathology. A low dose dexamethasone suppression test demonstrated suppression of baseline values of cortisol and DHEAS from 437 to $36 \mathrm{nmol} / \mathrm{L}$ and 1.2 to $<0.8 \mathrm{nmol} / \mathrm{L}$, respectively, whereas testosterone did not suppress (6.3 to $5.7 \mathrm{nmol} / \mathrm{L}$ ), suggesting that the elevated testosterone was mainly ovarian in origin. Trans-vaginal ultrasound showed bilateral solid heterogeneous adnexal masses. Treatment options were discussed with the patient and she elected for a bilateral oophorectomy (October 2006) as opposed to medical treatment with GnRH agonists. Following surgery the left $(50 \times 30 \times 25 \mathrm{~mm})$ and right $(60 \times 30 \times 20 \mathrm{~mm})$ ovaries were seen to contain subcapsular tan nodules, corpora albicans on the surface and the ovarian tissue had been replaced by a uniform ochre-coloured tissue, these findings consistent with stromal hyperthecosis.

The testosterone levels normalised post-operatively (within 2 weeks) and the patient reported improvements in both hirsutism and baldness at the six-week review. Subsequently the glycaemic control (Table 1, Figure 1) worsened despite no change in the patient's weight and lifestyle. Within 4 months an extra 100 units/day (124 to 224 units/day) of insulin were required, but 
Table 1 Patient data (when available) before and after oophorectomy highlighting the change in glycaemic control and the increase in insulin requirement.

\begin{tabular}{|c|c|c|c|c|c|c|c|c|c|c|}
\hline & $\begin{array}{l}\text { Weight } \\
\text { (kg) }\end{array}$ & $\begin{array}{l}\text { Insulin } \\
\text { (Units/day) }\end{array}$ & $\begin{array}{l}\mathrm{HbA}_{1 \mathrm{c}} \\
(\% / \mathrm{mmol} / \\
\mathrm{mol})\end{array}$ & $\begin{array}{l}\text { Total } \\
\text { cholesterol } \\
\text { (mmol/L) }\end{array}$ & $\begin{array}{l}\text { Triglyceride } \\
\text { (mmol/L) }\end{array}$ & $\begin{array}{l}\text { HDL-C } \\
\text { (mmol/L) }\end{array}$ & $\begin{array}{l}\text { LDL-C } \\
\text { (mmol/L) }\end{array}$ & $\begin{array}{l}\text { Y-glutamyl } \\
\text { transferase } \\
\text { (IU/L) }\end{array}$ & $\begin{array}{l}\text { Testosterone } \\
\text { (nmol/L) }\end{array}$ & $\begin{array}{l}\text { SHBG } \\
\text { (nmol/L) }\end{array}$ \\
\hline Jan-02 & & & $9.4 / 79.0$ & 6.0 & 8.8 & & & 509 & & \\
\hline Oct-03 & & 138 & $6.8 / 50.8$ & 4.9 & 2.2 & 1.0 & 2.9 & 193 & & \\
\hline Oct-04 & 107.2 & 138 & $7.0 / 53.0$ & 5.0 & 2.2 & 1.1 & 2.9 & 143 & & \\
\hline Jan-05 & 106.2 & 138 & $6.5 / 47.5$ & 4.6 & 2.1 & 1.0 & & & & \\
\hline Sep-05 & 106.9 & 124 & & & & & & & 9.7 & 14.7 \\
\hline Nov-05 & & 124 & & & & & & & 6.3 & \\
\hline Dec-05 & 109.0 & 124 & $7.2 / 55.2$ & 5.1 & 2.9 & 1.2 & 2.6 & 199 & 7.2 & 12.0 \\
\hline Feb-06 & 110.0 & 124 & & & & & & & 7.2 & 13.2 \\
\hline Jul-06 & 109.5 & 124 & $7.4 / 57.4$ & & & & & 202 & 6.6 & \\
\hline May-07 & 105.1 & 224 & $9.4 / 79.2$ & 5.5 & 2.6 & 1.2 & 3.1 & 627 & & \\
\hline Jul-07 & 107.8 & 224 & $8.9 / 73.8$ & 5.6 & 2.2 & 1.3 & 3.3 & 583 & 0.2 & \\
\hline Sep-07 & & 234 & $9.5 / 80.3$ & 5.2 & 2.2 & 1.2 & 3 & 612 & & \\
\hline Feb-08 & & 268 & $8.9 / 73.8$ & 5.5 & 2.4 & 1.3 & 3.1 & & 0.3 & \\
\hline Mar-09 & 109.0 & 288 & $8.5 / 69.4$ & & & & & 679 & 0.3 & \\
\hline May-09 & & 292 & $7.8 / 61.7$ & 5.9 & 2.3 & 1 & 3.8 & 546 & 0.6 & 23.5 \\
\hline Aug-09 & 105.0 & 292 & $7.4 / 57.4$ & 6.3 & 1.9 & 1.1 & 4.3 & & 0.7 & 24.3 \\
\hline Nov-10 & 108.0 & 302 & $7.3 / 56.3$ & 5.8 & 1.8 & 1.1 & 3.9 & 447 & 0.5 & \\
\hline May-11 & 110.0 & 300 & $7.1 / 54.1$ & 5.6 & 1.1 & 1.4 & 3.4 & 386 & 0.4 & \\
\hline Nov-11 & 108.0 & 300 & $7.1 / 54.1$ & 6.7 & 2.4 & 1.4 & 4.2 & 433 & 0.3 & \\
\hline
\end{tabular}

Figure 1. Change of insulin dose and testosterone levels over time (month/year).

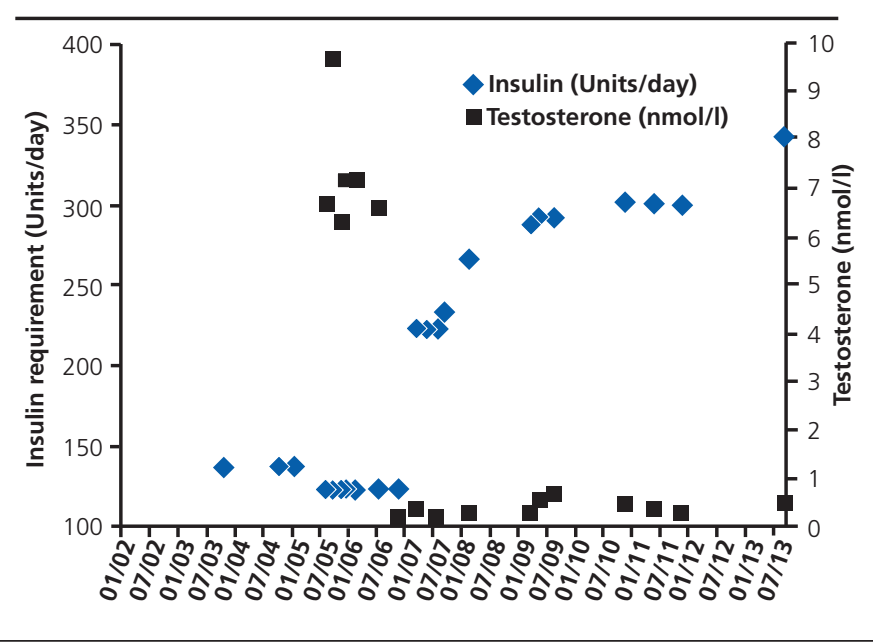

despite that, the $\mathrm{HbA}_{1 \mathrm{c}}$ had risen from $7.4 \%$ (57.4 $\mathrm{mmol} / \mathrm{mol}$ ) to $9.4 \%$ (79.2 $\mathrm{mmol} / \mathrm{mol})$. A further 68 units/day were required to improve the $\mathrm{HbA}_{1 \mathrm{c}}$ to pre-operative values $(7.4 \%$ (57.4 $\mathrm{mmol} / \mathrm{mol})$ ). There was also a deterioration in GGT levels which increased from pre-operative levels of approximately 200 to $>500 \mathrm{IU} / \mathrm{L}$ (Table 1), mirrored to a lesser extent by ALT (from 35 to peak at $82 \mathrm{IU} / \mathrm{L}$ ) which could be due to deteriorating hepatic steatosis. The cause of this cannot be elucidated but may be due to worsening of diabetes. Table 1 shows pre and post-operative details of weight, insulin requirement and biochemistry and Figure 1 graphically illustrates the change in glycaemic control coinciding with surgery.

All hormones were measured using Roche methodology (electrochemiluminescence, MODULAR ${ }^{\circledR}$ E170 analyser, Roche, Burgess Hill, UK) except androstenedione (chemiluminescence immunoassay, Immulite 2000, Diagnostic Products Corporation). $\mathrm{HbA}_{1 \mathrm{c}}$ was measured by National Glycohemoglobin Standardisation Program certified HPLC (TOSOH Bioscience Ltd., Redditch, UK).

\section{Discussion}

This report describes a post-menopausal diabetic patient with greatly elevated testosterone who was diagnosed as having hyperthecosis. Contrary to our expectation, post-operatively her glycaemic control deteriorated significantly despite no change 
in either weight or lifestyle. The GGT also increased, perhaps due to worsening fatty liver associated with the deteriorating glycaemic control, although this is speculation as liver biopsies were not carried out. There is no ready explanation for the change in glycaemic control.

There is a scarcity of data concerning the change in glycaemic control following an abrupt decrease in testosterone levels in post-menopausal patients. Barth et al described four cases (two had type 2 diabetes) of post-menopausal hyperthecosis. Treatment with GnRH agonists significantly reduced testosterone and hirsutism in three patients (the other patient died), but no data on hyperglycaemia were presented. ${ }^{3}$ Another case of postmenopausal hyperthecosis with type 2 diabetes reported improvement of $\mathrm{HbA}_{1 \mathrm{c}}$ following oophorectomy, from $10.1 \%$ to $8.2 \%$, which required cessation of gliclazide due to hypoglycaemia. ${ }^{2}$ More data are available in patients with PCOS, which is associated with increased androgens (albeit at lower levels), and insulin resistance. Studies of the treatment of PCOS with anti-androgen therapies are however contradictory, often depending on the exact agent used, demonstrating improvement, no change and worsening of hyperinsulinism.

It appears that a relationship is present between androgens and insulin resistance. A raised testosterone level in women has been associated with insulin resistance, ${ }^{4}$ the opposite to men. ${ }^{5}$ Androgens reduce SHBG levels and SHBG has been observed to be negatively correlated with insulin resistance. ${ }^{5}$ Low SHBG levels have been associated with the onset of type 2 diabetes. ${ }^{5}$ Insulin receptors present on the ovary and insulin-like growth factors enhance LH-dependent ovarian androgen synthesis and remain sensitive despite the presence of generalised insulin resistance. ${ }^{6}$ Thus, a complex mechanism may exist where hyperandrogenism leads to insulin resistance and hyperinsulinism which in turn may result in the elevated insulin stimulating androgen release. It is tempting to speculate that an oophorectomy could disrupt this circular relationship. It is important to restate that, as the preoperative testosterone concentration was greatly elevated, these associations may not apply.

This is the first case report of clinical resolution of the hyperthecosis with unexpected worsening of glycaemic control. The rapidity of the deterioration of glycaemic control without significant weight change may suggest that abrupt reduction in ovarian androgens has an aetiological role. Although we can but

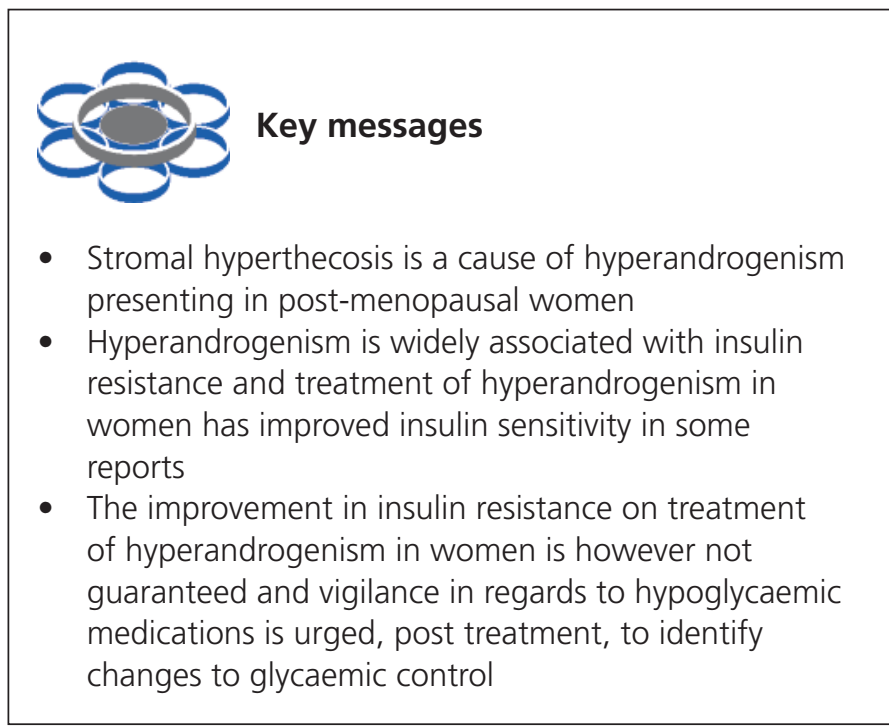

speculate on the reasons, it is possibly of benefit if glycaemic control is assessed in all patients where treatment leads to changes in androgen levels.

\section{Conflict of interest None. \\ Funding sources None.}

Acknowledgements The authors would like to thank the patient for her consent to publish the case.

\section{References}

1. Chang RJ. A practical approach to the diagnosis of polycystic ovary syndrome. Am J Obstet Gynecol 2004;191:713-17. http://dx.doi.org/10.1016/j.ajog.2004.04.045

2. Leedman PJ, Bierre AR, Martin Fl. Virilizing nodular ovarian stomal hyperthecosis, diabetes mellitus and insulin resistance in a postmenopausal woman. Case report. Br J Obstet Gynecol 1989;96:1095-8. http://dx.doi.org/10.1111/j.1471-0528.1989.tb03388.x

3. Barth JH, Jenkins $M$, Belchetz PE. Ovarian hyperthecosis, diabetes and hirsuties in post-menopausal women. Clin Endocrinol 1997;46:123-8. http://dx.doi.org/10.1046/j.1365-2265.1997.1050916.x

4. Corbould A. Effects of androgens on insulin action in women: is androgen excess a component of female metabolic syndrome? Diabetes Metab Res Rev 2008;24:520-32. http://dx.doi.org/10.1002/dmrr.872

5. Ding EL, Song Y, Manson JE et al. Sex hormone-binding globulin and risk of type 2 diabetes in women and men. N Engl J Med 2009;361: 1152-63. http://dx.doi.org/10.1056/NEJMoa0804381

6. Nandi A, Poretsky L. Diabetes and the reproductive system. Endocrinol Metab North Am 2013;42:915-46.

http://dx.doi.org/10.1016/j.ecl.2013.07.007 